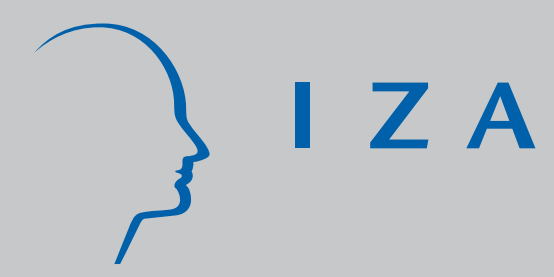

IZA DP No. 3082

Disparities in Labor Market Outcomes across

Geopolitical Regions in Nigeria: Fact or Fantasy?

Ruth Uwaifo Oyelere

September 2007 


\title{
Disparities in Labor Market Outcomes across Geopolitical Regions in Nigeria: Fact or Fantasy?
}

\author{
Ruth Uwaifo Oyelere \\ Georgia Institute of Technology \\ and IZA
}
Discussion Paper No. 3082
September 2007

\author{
IZA \\ P.O. Box 7240 \\ 53072 Bonn \\ Germany \\ Phone: +49-228-3894-0 \\ Fax: +49-228-3894-180 \\ E-mail: iza@iza.org
}

\begin{abstract}
Any opinions expressed here are those of the author(s) and not those of the institute. Research disseminated by IZA may include views on policy, but the institute itself takes no institutional policy positions.

The Institute for the Study of Labor (IZA) in Bonn is a local and virtual international research center and a place of communication between science, politics and business. IZA is an independent nonprofit company supported by Deutsche Post World Net. The center is associated with the University of Bonn and offers a stimulating research environment through its research networks, research support, and visitors and doctoral programs. IZA engages in (i) original and internationally competitive research in all fields of labor economics, (ii) development of policy concepts, and (iii) dissemination of research results and concepts to the interested public.
\end{abstract}

IZA Discussion Papers often represent preliminary work and are circulated to encourage discussion. Citation of such a paper should account for its provisional character. A revised version may be available directly from the author. 
IZA Discussion Paper No. 3082

September 2007

\section{ABSTRACT \\ Disparities in Labor Market Outcomes across Geopolitical Regions in Nigeria: Fact or Fantasy?}

Differences in geopolitical regions of Nigeria are not debatable. However, there is no clear consensus on the dimension of these disparities. In this paper, claims of geopolitical region disparities in labor market outcomes are investigated using survey data from Nigeria between 1996-1999. Both descriptive and econometric analysis are used to test the null hypothesis that there are no significant regional differences in labor market outcomes in Nigeria. The results are surprising given the anecdotal evidence and general perception of disparities along this dimension. First, similar mean incomes across regions in Nigeria were noted. In addition, returns to education were not significantly different for Northern and Southern Nigeria. Given these findings, the null hypothesis cannot be rejected. There is no evidence of significant disparities in labor market outcome across geopolitical regions in Nigeria.

JEL Classification: $\quad 05,10, \mathrm{~J} 70, \mathrm{O} 18$

Keywords: regional disparities, labor market outcomes, Nigeria, returns to education, inequality

Corresponding author:

Ruth Uwaifo Oyelere

School of Economics

Georgia Institute of Technology

781 Marietta Street

Atlanta Georgia, 30318

USA

E-mail: ruth.uwaifo@econ.gatech.edu 


\section{Introduction}

Questions focused on understanding Africa's lack of growth are not new in economics research. Ethnic fragmentation is one of the many reasons suggested for lack of growth of many developing countries especially in Africa. This is because many countries that are ethnically fragmentized find it difficult agreeing on societal goals and instead, focus on achieving dominance in the political arena of the country. These actions usually lead to: ethnic conflict, corruption, instability and other factors that in the long-run hamper growth. Nigeria is no stranger to the scenario described above. For example, Obadina (1999) noted that competition for power and resources between the three main ethnic groupings in Nigeria: the Hausa-Fulani in the north, the Yoruba in the southwest and the Igbo in the southeast has contributed to a turbulent political history that has helped to stall national economic development.

The basis of most ethnic/regional conflict are claims of the marginalization of particular groups, government overtly favoring certain groups and specific groups benefitting more from the countries wealth than others. Documented and anecdotal evidence of marked differences in basic economic and social indicators are usually the starting point for these assertions. However, general perception and beliefs have played a role in solidifying these.

Assertions of disparities across regions have existed ever since Nigeria's independence (see Aka, 2000). According to the Human development report of 1994, regional disparities in Nigeria are amongst the worst in the world. When states in Nigeria were ranked by the UNDP in its 1994 Human Development Report, the state of Bendel was top with an HDI index nearly five times as great as that for Borno state which had an HDI index lower than that of any country in the world. Moreover, disparities have been associated with Nigeria's failed federalism and rapid movement to a more 
central government post independence (see Wantchekon \& Asadurian 2002, for more on regional disparities and Suberu, $2001 \&$ Soyinka, 1997 for regions and the Nigerian crises). Over the years, claims of regional disparities and marginalization have increased dramatically. Some of the main areas of contention have been disparities in income, education, amenities, power and labor market outcomes (World Bank, 1995, Aka, 2000, Kosemani, 1993). In this paper, disparities in labor market outcomes with respect to income and returns to education will be examined.

Many demographic and social dimensions of disparities across regions in Nigeria have been documented by its Federal Office of Statistics (FOS) (see also Aka, 2000 and Wantchekon \& Asadurian, 2002 for more evidence). ${ }^{1}$ However, the lack of economic evidence of regional differences in labor market outcomes in Nigeria, despite claims to this effect, is the basis for investigating this dimension. Labor market outcomes have been analyzed in several ways over time. Two standard ways of looking at these outcomes are to calculate average wages and to estimate the returns to education using econometric techniques. In general, regions in proximity as within a country should have similar labor market outcomes like returns to education or real wages. This statement is based on the assumption that labor can move freely within a country. Hence, labor would keep moving among regions until income and returns to labor across regions are equalized. With respect to Nigeria, there are road blocks to free labor movement across regions. Examples of such road blocks are language, ethnicity, religion and culture. Labor market disparities are possible given this scenario but such assertions need to be substantiated with economic evidence.

Nigeria is the most populous country in Africa (one out of every five Africans is Nigerian) and also one of the most ethnically diverse with over 200 ethnic groups and 354 languages. Before colonial rule, Nigeria did not exist and the area mapped out 
as Nigeria held several distinct kingdoms each with its unique culture and heritage. Before the British take over in the nineteenth century, these kingdoms clashed regularly in an attempts to assert individual dominance and superiority. After the take over of most parts of Africa by the Europeans, the region was divided arbitrarily mainly between the French and British. Nigeria was created now containing many different kingdoms and parts of some kingdoms. Before Nigeria was created, the British in an attempt to control effectively the area now called Nigeria, divided it first into two regions (North and South). These regions were later amalgamated to make Nigeria. However, the existence of several unique kingdoms within these regions necessitated further divisions as major groups sought their own niche amidst clashes and claims of marginalization. Today there are thirty six states in Nigeria excluding Abuja the capital, yet the demand for further division still exists. ${ }^{2}$

Presently the thirty six states in Nigeria can be classed into six geopolitical regions: the Northeast (NE), North-central (NC), the Mid-belt (MB), the Southeast (SE), Southwest (SW) and the South-South (SS) (see Figure one showing states and regions in Nigeria $^{3}$ ). As reflected in Figure 1, these six regions are not entirely carved out based on geographical location. States with similar cultures, ethnic groups and common history, were classed in the same region. This is one reason why regions in Nigeria are geopolitical in nature. Table one also presents a concise summary of the main characteristics of the six geopolitical regions in Nigeria. From this table there is evidence that regions in Nigeria do have different backgrounds and unique features. However, these differences do not indicate economic disparities across regions.

Substantial evidence of geopolitical differences in education attainment, school quality, education expenditure and school enrollment exist in Nigeria (see Kosemani, 1993; Malik, 1997; Aluede, 2006). Given the disparities in these aspects of education, 
its understandable why claims of regional differences in the benefits from education exist. Moreover, the role of education has come under scrutiny in some parts of Nigeria over the last twenty years and primary enrollment rates in these regions plummeted (FOS 2001). In the late 90s, skepticism towards education and its benefits was linked partially to claims of the persistence of the uneducated rich especially in the Northern parts of the country and an increase in the educated poor in other regions. Furthermore, the growing opinion that education has little value and having the right social network or belonging to a certain ethnic group matters more for income determination only heightened negative attitude towards education in certain regions. For example, in the eastern parts of Nigeria, this attitude has led to a prevalent problem termed the boy-child drop-out syndrome. Mkpa (2000) noted that boys for economic reasons refuse to go to school and those who enter primary schools drop out prematurely. They refuse to complete primary and secondary education because of the economic problems encountered by the educated in their society. Given this disturbing trend and its consequences, it is important to verify the existence of disparities in benefits from education across region.

In this paper, evidence of labor market disparities in Nigeria is sought first using descriptive analysis of the data. Subsequently, the null hypothesis that there are no significant differences in labor market outcomes across geopolitical regions is tested using econometric techniques. Using an instrument first suggested by Osilli and Long (2003) but constructed similarly to Uwaifo (2006), the returns to education are estimated using two stage least squares. Estimates for both Northern and Southern Nigeria are derived. This instrument is based on the exogenous implementation and withdrawal of free education across regions and states in Nigeria over time.

The findings are surprising given the general perception and anecdotal evidence. 
First, mean incomes were similar across regions in 1997/98 and 1998/99. However, when labor is classified by education levels the results change. At each educated level, disparities in mean income across regions were noted. In particular, substantial differences across regions were noted for the sample with tertiary education. Second and more importantly, the null hypothesis is not rejected. Returns to education in the North and South of Nigeria are not significantly different.

This paper contributes to the literature in three ways. First, the paper provides evidence of similarity in labor market outcomes in Southern and Northern Nigeria. This is a very important finding given the anecdotal evidence and general perception of such disparities. Second, the results highlight the importance of not depending solely on descriptive analysis but using analytical tools to search for evidence and test simple hypothesis. Finally, the findings in this paper provide further evidence in support of the low returns to education problem in Africa first noted in Uwaifo (2006).

The remainder of this paper is organized as follow: In the next section the data used in this analysis is described. In section three the descriptive analysis and evidence is presented. In section four the estimation techniques, identification strategy and econometric analysis are highlighted. A summary of the results, conclusions and implications are in the last section.

\section{Description of data sets}

This study makes use of cross-sectional data from the General Household Survey (GHS) of Nigeria. The GHS is one of the major sample surveys carried out by the federal office of statistics(FOS). This survey is a supplemental module of the National Integrated Survey of Households (NISH) which is run in line with the United Nations Household Survey Capability Program. This survey sample was drawn randomly from all the 36 states in Nigeria including the federal capital territory. The NISH sampling design is 
a two-stage replicate sample method, which is a common random sampling procedure. It is the only survey in Nigeria that resembles the Living Standards Measurement Survey (LSMS) of the World Bank in terms of variable coverage. The Federal Office of Statistics in Nigeria conducts this survey yearly and data are collected from randomly selected households during the four quarters of the year ${ }^{4}$. I use data from 1996/97, 1997/1998 and 1998/1999. This dataset contains information on 27649 households in 1996/97 with 88636 observations, 32024 households in 1997/98 with 131477 observations, 24889 households in 1998/99 with 106,325 observations. Data from these three surveys are comparable as the same sampling procedure was used in the three surveys. To ensure that the data are comparable over time as is necessary when using income data, monetary variables were deflated to base year prices ${ }^{5}$.

This dataset is appropriate for the analysis since it consists of detailed information on every member of the household and economic indicators for these individuals. A drawback of the survey is that different households are surveyed in each survey year ${ }^{6}$. This dataset contains information about education attainments of every member of the households and also contains monthly income for those working. In Table two, summary statistics are highlighted for each year of data considered. The summary statistics across the three years of the survey look very similar for all variables apart from mean income. A close analysis at the income entries in 1996/97 dataset revealed the presence of some very high income entries. These observations cannot be simply dismissed as outliers. First, there are quite a number of these kinds of observations. Second, these high income observations are located in the three Northern regions of Nigeria. During the $80 \mathrm{~s}$ and 90 s, the north was politically dominant and these high income observations may reflect income benefit of this dominance. However, as this high income trend does not continue in the two subsequent years of data considered, 
in spite of the continued Northern dominance, the possibility that these income values are measurement errors cannot be ruled out. In addition, some of the observations with high income entries exhibit poverty correlates in other variables, further casting doubt on their validity. For example, some of the high income observations lived in mud houses and did not have portable water or electricity ${ }^{7}$.

\section{Descriptive evidence for differences in labor mar- ket outcomes}

The first variable to consider when looking for regional differences in labor market outcomes is income. Not only are wages a good indicator of labor market outcomes but anecdotal evidence and data evidence point to strong disparities in income across Nigeria (FOS 2001). Moreover, a general stereotype prior to democracy in Nigeria was that the northern regions in Nigeria were better of income wise than the southern regions. This representation is based on the political dominance of the North for most of the 90s. Table three provides a summary of mean income across regions in Nigeria over the three periods of the data set and pooling the datasets together. To compare mean income across regions, simple $t$ tests for significant differences were conducted. The results provide evidence for regional differences in income in 1996/97. ${ }^{8}$ Given the possibility of measurement error in this dataset, focus would be placed on the other two data periods: 1997/98 and 1998/99. Interestingly, if we focus solely on these two periods, there is less evidence of significant differences in mean income across most regions. The largest difference in income between two regions is 22 naira in 1997/88 and 29 naira in 1998/99. Though these differences may be statistically significant, disparities are not economically substantial. This result is very surprising given general perception and anecdotal evidence of income disparities in Nigeria at this time. This

simple analysis seems to indicate that there is no substantial income disparities across 
regions.

Labor market outcomes in terms of mean income were also analyzed at each education level. This analysis is especially relevant given the growing view during this period that education was not very useful for income determination in some regions of the country. Many Southern Nigerians believed that education mattered less in the North for income determination because of the northern dominance in the political arena (see Lewis et al, 1998 for more on northern dominance). Table 4-6 are summary tables of mean income by education level for each region. Interestingly, though the lack of substantial difference across regions in mean income noted in Table 3 , there is evidence for regional differences in mean income when each level of education is considered separately. ${ }^{9}$ These differences are not only statistically significant but increase with the level of education. The findings in Table 5-6 are surprising for various reasons. First, given the similarities in mean income noted in Table 3, disparities at the subgroup level are not expected. This is because at the subgroup level, observations with the same level of education are being compared. Hence the economic expectation, assuming free movement of labor across regions, is that mean income should be similar. Second, disparities increasing with the level of education are a reverse expectation given the political climate in Nigeria during this period. ${ }^{10}$ Substantial disparities in favor of northern regions are expected at the lower level of education. In contrast, the results provide evidence of more disparities at the higher levels of education. Moreover these disparities are not in favor of the north or south but more arbitrary across region. It is also important to mention that the differences at higher levels of education are substantial economically. Notice that real incomes are presented in Table 4-6 and what may seem like a small difference is substantial in current terms. For example in Table 5, the difference in mean income between the region with the lowest mean 
income and highest mean income for tertiary education in current Naira is about 1500 Naira per month.

It is important to state that Tables five \& six provide clear evidence that education does matter for income determination. Notice that mean income rose with the level of education in each region. This is a positive finding that refutes the hypothesis that education does not matter in some regions in Nigeria. Figure two, which captures the median spline graph of income over educational attainment for each region, provides results consistent with this finding. The question of whether education matters less in the North than South is however more difficult to answer. Table 4's results are consistent with the view that education mattered much less in the North. However, inference based on Table 4 are not made given the possible measurement errors in the 1996/97 data. From Table five and six, there is some evidence that education mattered slightly less in the north than the south. ${ }^{11}$ In addition, the steeper median spline graphs for the Southern regions in Figure two also suggest that the benefits of education are higher in the South. Unfortunately, the descriptive evidence from Table 4-6 and Figure two are simply suggestive. They do not serve as concrete evidence for the claim. In the next section, analytical tools are used to provide concrete evidence in support or against this claim.

The descriptive findings in this section are mixed and cannot be used to test the null hypothesis. Evidence for and against disparities in labor market outcomes across regions were noted. Mean income across regions is similar but regional disparities in mean income at each education level exist. These results seem contradictory but it is possible that regional disparities in mean income by level of education are only a reflection of other factors in the region. Hence, the only way to test the posed hypothesis effectively is to use econometric techniques that can control for several factors. 
In the next section, the average returns to education are estimated for Northern and Southern Nigeria to test this hypothesis.

\section{Econometric evidence for differences in labor mar- ket outcomes}

In this section, the null hypothesis is tested using econometric techniques. The labor market outcome considered is returns to education. The return to education is a standard labor market outcome for quantifying private benefits of schooling. In this analysis, the wage equation framework will be used which is the most common approach for estimation of the returns to education.

\subsection{Estimating returns to education across regions}

To investigate claims of disparities in labor market outcomes across regions, returns to education across regions are estimated using a Mincer type earnings function (Mincer 1974) like equation $1 . \quad b$ which is the returns to education is first estimated using ordinary least squares (OLS) as a bench mark. Equation 1 is estimated by region, pooling the data from 1996-1999. Several controls like gender, state, year dummies and sectors are included in matrix D to improve the precision of the regression estimates.

$$
\log (Y)=\alpha+b S+\phi X+\kappa X^{2}+\rho D+\epsilon
$$

Here $Y$ is a vector of income or wage of individuals in the sample, $S$ is a vector of the years of schooling of observations, $X$ is a vector of years of experience, $D$ is a matrix of all other possible exogenous/control variables affecting income and $\epsilon$ is the error term.

It is important to mention that the returns to education $b$ estimated using OLS potentially suffer from endogeniety and omitted variable bias (Card, 1999). To deal 
with this problem and ensure identification, the returns to schooling are re-estimated for each region using instrumental variables (IV) in a two stage least squares estimation of equations 2 and 3. The assumption here is that schooling $S$ is a function of several variables including the instrument. ${ }^{12}$ There are several papers estimating the returns to education using the IV approach mostly in developed countries (see Card, 1999). Duflo (2001) is the best known paper using the IV technique to estimate the returns to education in a developing country.

$$
\begin{gathered}
\log (Y)=\alpha+\phi X+\kappa X^{2}+\rho D+\beta S+\epsilon \\
S_{i}=\delta+\varphi Z+v
\end{gathered}
$$

Note: $X$ and $S$ are the same as above. Here $D$ and $Z$ are matrices of explanatory variables ${ }^{13}$, $\epsilon$ and $v$ are vectors of uncorrelated error terms, $\alpha$ and $\delta$ are the intercept terms and $\beta$ is the return to education/schooling.

\subsubsection{Understanding the Instrument: Description and Construction}

As mentioned earlier, the empirical strategy for adequately estimating $\beta$ requires the use of an instrument. The instrument for schooling used in this paper is the length of exposure to the Universal Primary Education (UPE) program in Nigeria. The original idea for this instrument came from Osilli and Longs (2003) paper on the impact of education on fertility in Nigeria. However, the instrument was constructed as in Uwaifo (2006). The UPE program was designed to increase educational attainment with different periods of implementation and withdrawal of the program across states/regions. Details of the program, its impact and the timeline of its implementation are in Nwanchukwu (1981), Osilli and Long (2003) and Uwaifo (2006). In addition, information on the free education program, the exposure or non exposure to the program and the intensity of the program across regions, states and sectors are 
based on historical facts documented by authors including Fafunwa (1974), Ozigi \& Ocho, (1981), Mazonde (1995) and Haas et al (2003). Based on detailed information from these sources, Uwaifo (2006) constructs the instrument. The instrument simply captures length of exposure to free education based on an interaction of year of birth and place of birth. The variation in the instrument comes from differences in length of exposure of cohorts in different regions, states or sectors to free education.

Recently, there has been a lot of controversy on the IV approach and the validity of many IV estimates (see Staiger and Stock, 1997). Critics of the IV approach argue that many instruments do not meet the criteria for a valid instrument and many instruments are weak. This is not the case in this analysis as the UPE instrument meets the three criteria of a valid instrument: relevance, exogenous and satisfies exclusion restrictions. ${ }^{14}$ Moreover, the instrument is not weak when analyzed at the country level, across gender or across sector. The exception is the analysis of the returns to education by region. This is because within regions variation in the instrument is quite low. Hence, the instrument becomes weak and IV estimates of returns to education by region may not be valid. In this case, OLS estimates are usually less biased than the weak IV estimates of returns to education.

Based on this information, only OLS estimates of returns to education for the six regions are calculated. However, as there is adequate variation in the instrument when simply comparing the North to the South, instrumental variable estimates for Northern and Southern Nigeria are estimated. In Uwaifo (2006), estimates were derived for the whole population but in this analysis, specific cohort are focused on. ${ }^{15}$ This approach is similar to that used by Osilli and Long (2003) and Duflo (2001). When focus is specifically directed at the cohort born within a range of the program implementation, the predictive power of the IV is maximized. Hence, consistent estimates of returns 
to education are derived. The argument against this approach is the fact that the returns to education estimates derived, only represent the returns for the cohorts focused on in contrast to estimates for the general population. However in the Nigerian case, the returns to education estimated using these cohorts can be generalized to the population. This is because robustness checks in Uwaifo (2006) results provide evidence of no significant differences in returns to education across cohorts in Nigeria.

Apart from deriving the IV estimates, OLS estimates for North and Southern Nigeria are also derived as a bench mark for comparison.

\subsection{Results for the IV and OLS analysis}

As highlighted earlier, equations 1 is estimated first using OLS as a benchmark. Subsequently, equation 2 and 3 are estimated using 2SLS with the IV. Only the pooled estimates of returns to schooling are derived. Uwaifo (2006) demonstrates the importance of adding controls to the wage equation, to avoid overstating the returns to schooling. Hence, similar controls are used in the estimation of equation 1-3. Examples of the controls include age and higher powers of age, sex, sector of the economy, year dummies, region dummies and cohort dummies.

Table 7 is a summary of the OLS estimates of returns to education by region. From Table 7, the OLS estimates seem to point to regional differences in returns to education. Higher returns to education were noted in the Southern regions and lower returns in the Northern regions. Despite this finding, conclusion on disparities in returns to education across regions in Nigeria are not inferred. This is because of the potential for bias in the OLS estimates in Table 7. However, like the descriptive evidence in the last section, the OLS results suggest that education matters more in the South than the North.

In Table 8 and 9, the results of the IV approach are summarized. Table 8 sum- 
marizes the first stage of the regression and Table 9 the second. The results are interesting. From table 8, evidence of differing regional impacts of the program on school attainment are noted. The program had stronger effects in the North versus the South. This is expected given the history of the program. In table 9, returns to education for North and South Nigeria are presented. First, returns are lower in the north $(4.3 \%)$ than in the South $(5.4 \%)$. The estimates in Table 8 imply a $4.3 \%$ increase in income for every extra year of schooling in the North and a 5.3\% increase in income for every extra year of schooling in the South. However, a simple t-test shows that these estimates are not significantly different. Meaning that there are no disparities in returns to education between Northern and Southern Nigeria.

Another important finding is that the IV estimates for both Northern and Southern Nigeria are higher than the OLS estimates. However, the IV estimates of returns to schooling are not significantly different from the OLS estimates in the South. For the North, this difference is statistically significant. Hence, this result suggests that OLS estimates are downward biased only in Northern Nigeria. This is a controversial finding. Based on the omitted variable and endogeniety argument in the literature, OLS estimates for returns to education are expected to be biased upward. However, finding a downward bias instead of an upward bias is not new in the literature ${ }^{16}$. Uwaifo (2006) also noted this trend when comparing IV and OLS estimates of returns to education.

Several reasons have been postulated for this difference. Angrist and Krueger (1991) and Card (2001) demonstrate that OLS estimates are typically lower than IV estimates as the downward bias resulting from measurement error is often bigger than the upward bias due to omitted variables such as ability. This is especially relevant in developing countries where we expect more measurement errors in variables such as 
school attainment. In addition, due to differences in the quality of education within many developing countries, years of schooling might be a noisy estimator of acquiring knowledge. A noisy estimator increases the measurement errors in the schooling variable and leads to further downward bias in OLS estimates. In Nigeria, differences in quality of education is much more apparent in the North than in the Southern geopolitical area (see Malik, 1997 and Yoloye, 1989 for disparities in quality of education in Nigeria). Hence, downward bias in the OLS estimates of returns to schooling for the North would be greater and may explain the greater disparity between the OLS and IV estimates in the North in comparison to the South.

The econometric results above provide no evidence of North South differences in returns to education in Nigeria. Based on this result, the null hypothesis cannot be rejected. There are no significant regional disparities in labor market outcomes in Nigeria despite claims of their existence.

\section{$5 \quad$ Summary and Conclusions}

In this paper, the question of regional disparities in labor market outcomes in Nigerian is addressed. First, this question was considered using descriptive tools. Subsequently, a major indicator of labor market outcomes, the return to education was estimated using OLS and the IV approach. The descriptive evidence was mixed but there seemed to be some evidence that education mattered more for income determination in the South. This potential result was tested in the analytical section along with the null hypothesis of no disparities in labor market outcomes across geopolitical regions in Nigeria. The income benefits of education as captured by returns to schooling estimates were derived for Northern and Southern Nigeria. Based on the econometric results, the null hypothesis cannot be rejected. Geopolitical disparities in labor market outcomes in Nigeria is not a fact but more a fantasy. These results are surprising given the 
general view of substantial geopolitical differences along this dimension in Nigeria, and the documented evidence of disparities in the education sector on other criteria. Moreover, the descriptive result of differences in mean income at each education level and figure 3 both seem to point to disparities in returns to education across geopolitical region. A possible explanation is that on average, returns to education is similar across geopolitical areas in Nigeria but the returns to certain levels of education may differ across regions. However, investigating this claim is beyond the scope of this paper. Another implication of the result is that though the returns to education in Nigeria is not substantial, education still yields some benefits. Furthermore, the results provide evidence that education matters equally in Northern and the Southern Nigeria.

In conclusion, evidence of geopolitical disparities in labor market outcomes as captured by the returns to education is not noted in Nigeria. The lack of regional disparities in labor market outcomes suggest easy labor mobility across regions within Nigeria. The result of this paper though surprising and contrary to expectation reflects a positive outcome. The results imply that income benefits from education are enjoyed at a similar rate in both the North and the South. Given the many documented dimensions of disparities across these two geopolitical areas, it is a positive result to find that labor market outcomes are not another dimension of disparity. However, what should be of more concern as noted in Uwaifo (2006) and confirmed by these results is the low returns to education estimates in Nigeria ${ }^{17}$ Understanding the reasons for low returns to education in Nigeria, despite expectation of high returns as evidenced in the literature, is not only interesting but useful for policy formation. Finally though disparities in labor market outcomes may not exist, other dimensions of geopolitical disparities do exist and some of these like poverty levels, school attainment and amenities have been documented (FOS 2001). The existence of other economic disparities 
across region have the potential to hamper growth, even when return to education disparities are not apparent. For example, regional conflicts that can reduce political stability and reduce growth can be fueled by the existence of disparities in political power or statuary allocations to states. Hence, policy and programs to close other properly documented disparity gaps is necessary. In addition, research on other potential sources of disparities not yet considered using economic methods is a must. As this paper shows, anecdotal evidence and general belief and claims could be fads and policy needs to be based on properly documented economic and statistical evidence and not on views, anecdotal evidence or beliefs. 


\section{Notes}

${ }^{1}$ Examples of documented geopolitical disparities include differences in school attainment, enrollment revenue generation, government expenditure and social services like water and electricity.

${ }^{2}$ The existence of a democracy in Nigeria is expected to bring the nation together and attenuate this segmentation drive.

${ }^{3}$ The six region classification is not the only accepted classification, some others choose to class Nigeria into five regions and not six. Also Nigeria can be divided into two broad categories North and South. The NE, NC, MB all belong to the North while the SE, SW and SS belong to the South.

${ }^{4}$ Different households in each enumeration area are interviewed in each quarter.

${ }^{5}$ Base year is 1985 .

${ }^{6}$ For the first quarter of 1998/99 the data set was not available.

${ }^{7}$ Living in a mud house or not having portable water are correlates of poverty and high income observations should normally have these basic amenities

${ }^{8}$ This result highlights the issues raised above with respect to the 1996/97 data. Mean income are very high for the North-East, North-Central and Mid-belt but the southern region estimates of mean income are similar across the three year period.

${ }^{9}$ Lower levels of education imply full primary education and below.

${ }^{10}$ At this time, the North was in power and northern social networks were supposed to be benefitting more from the government than other regions' social networks. However, school attainment was much lower in the north at this time. Given the lack of correlation between having political power and education during this period, the expectation is that benefitting networks in the north would be at lower levels of education. Hence, income disparity if they do exist would be at lower levels of education.

${ }^{11}$ This evidence is based on computing the income difference between the uneducated and tertiary educated in the North and South.

${ }^{12}$ In all the estimations, corrections are made for potential heteroscedasticity.

${ }^{13}$ Matrix Z contains the instruments for school as well as all the variables contained in D.

${ }^{14}$ In Uwaifo(2006) arguments about the validity of the instruments along these criteria are made to buttress the point that estimates of returns to education using this instrument are valid/consistent.

${ }^{15}$ For the North, relevant cohorts are those born between 1964 and 1977. While for the South, the cohort considered are those born between 1948 and 1977.

${ }^{16}$ Card, 1999 highlighted this trend in his review of papers estimating returns to education using the IV strategy.

${ }^{17}$ Although Uwaifo (2006) estimates of returns to education are lower than those found in this paper (about $3.6 \%$ for every extra year of schooling), they are not significantly different from the results here and both results are equally low. 


\section{References}

[1] Adesina, S. 1988. "The Development of Modern Education in Nigeria," Heineman Education Books, Ibadan.

[2] Aka, Ebenezer O. 2000. Regional Disparities in Nigeria's Development: Lessons and Challenges for the Twenty-first Century. Lanham, MD: University Press of America. 205 pp.

[3] Aluede R.O.A. 2006. "Regional Demands and Contemporary Educational Disparities in Nigeria" Journal Social. Science., 13(3): 183-189.

[4] Angrist, J. and A. Krueger 1991. "Does Compulsory School Attendance Affect Schooling and Earnings." Quarterly Journal of Economics 106: 979-1014.

[5] Card, D. 2001. "Estimating the Return to Schooling: Progress on Some Persistent Econometric Problems". Econometrica, vol. 69(5), pages 1127-60.

[6] Duflo, E. 2001. "Schooling and Labor Market Consequences of School Construction in Indonesia: Evidence from an Unusual Policy Experiment," American Economic Review, vol. 91, issue 4, pages 795-813.

[7] Fafunwa, B.A. 1974. "History of Education in Nigeria," London: Allen and Unwin, (New edition in 1991).

[8] Federal Office of Statistics (FOS) 2001. Annual abstract of statisitcs. Federal office of statistics.

[9] Haas, M.E., Sunal, C.S., Sunal, D.W., Rufai,R., Inuwa, A. 2003. "Perceptions of Unequal Access to Primary and Secondary Education: Findings from Nigeria." African Studies Review.

[10] Kosemani, J.M. 1993. "The historical background to contemporary educational disparity in Nigeria", in Educational Disparity: The Nigeria Situation. Africa Heritage Research and Publications. (In Press).

[11] Lewis, P.M., Barnett R. Rubin, Pearl T. Robinson 1998. Stabilizing Nigeria: Sanctions, Incentives, and Support for Civil Society. Published by Council on Foreign Relations Politics/ Current Events 152 pages ISBN 0870784153.

[12] Malik, M. 1997. "Education and the issue of quality," Education Today, 6 (1), $25-31$.

[13] Mazonde, I.N. 1995. "Culture and education in the development of Africa." Article available online at http://unpan1.un.org/intradoc/groups/public/documents/IDEP/UNPAN003347.pdf.

[14] Mincer, J. 1974. Schooling experience and earnings. New York NBER.

[15] Mkpa, M. A. 2000. "Overview of educational development: precolonial to present day," Article available on line at http : //www.onlinenigeria.com/links/eduadv.asp. 
[16] Nwachukwu, A.E. 1985. An Historical Analysis of the Roots of Universal Public Primary Education in Nigeria, (1900-1980) Unpublished PhD Dissertation University of Kansas.

[17] Obadina, T. "Nigeria's economy at the crossroads". Africa Recovery, Vol.13\#1 (June 1999), page 8.

[18] Osili, U. \& Long, B.T. 2003. "Universal Primary education and fertility: A Nigerian Experience," Paper presented at the NEUDEC conference 2003.

[19] Ozigi, A. \& Ocho, L. 1981. Education in Northern Nigeria, Winchester, MA:

[20] Soyinka, W. 1997. The Open Sore of a Continent: A Personal Narrative of the Nigerian Crisis. The W.E.B. Dubois Institute series.

[21] Staiger, D. \& J. Stock, 1997. "Instrumental Variable Regression with Weak Instruments", Econometrica, vol. 65, pp. 557-586.

[22] Suberu, R.T. 2001. Federalism and Ethnic Conflict in Nigeria, United States Institute of Peace: Washington, DC.

[23] Uwaifo, R.0. 2006. Three Essays on the Returns to Education Enigma in Nigeria. UC Berkeley, Unpublished PhD Dissertation.

[24] Wantchekon, Leonard \& Asadurian T. 2002. Transfer Dependence and Regional Disparities: the Case of Nigeria. Center for research on economic development and policy reform. No. 152 .

[25] World Bank 1995. Nigeria: Towards the Improved Delivery of Social Services Findings Africa Region No 47 . World Bank publication by the Africa Technical Department.

[26] Yoloye, E.A. (ed) 1989: "Resources for Science, Mathematics and Technical Education in Nigerian Secondary Schools A National Survey," A Report submitted to the Ministry of Science and Technology Lagos. 


\section{Appendix}

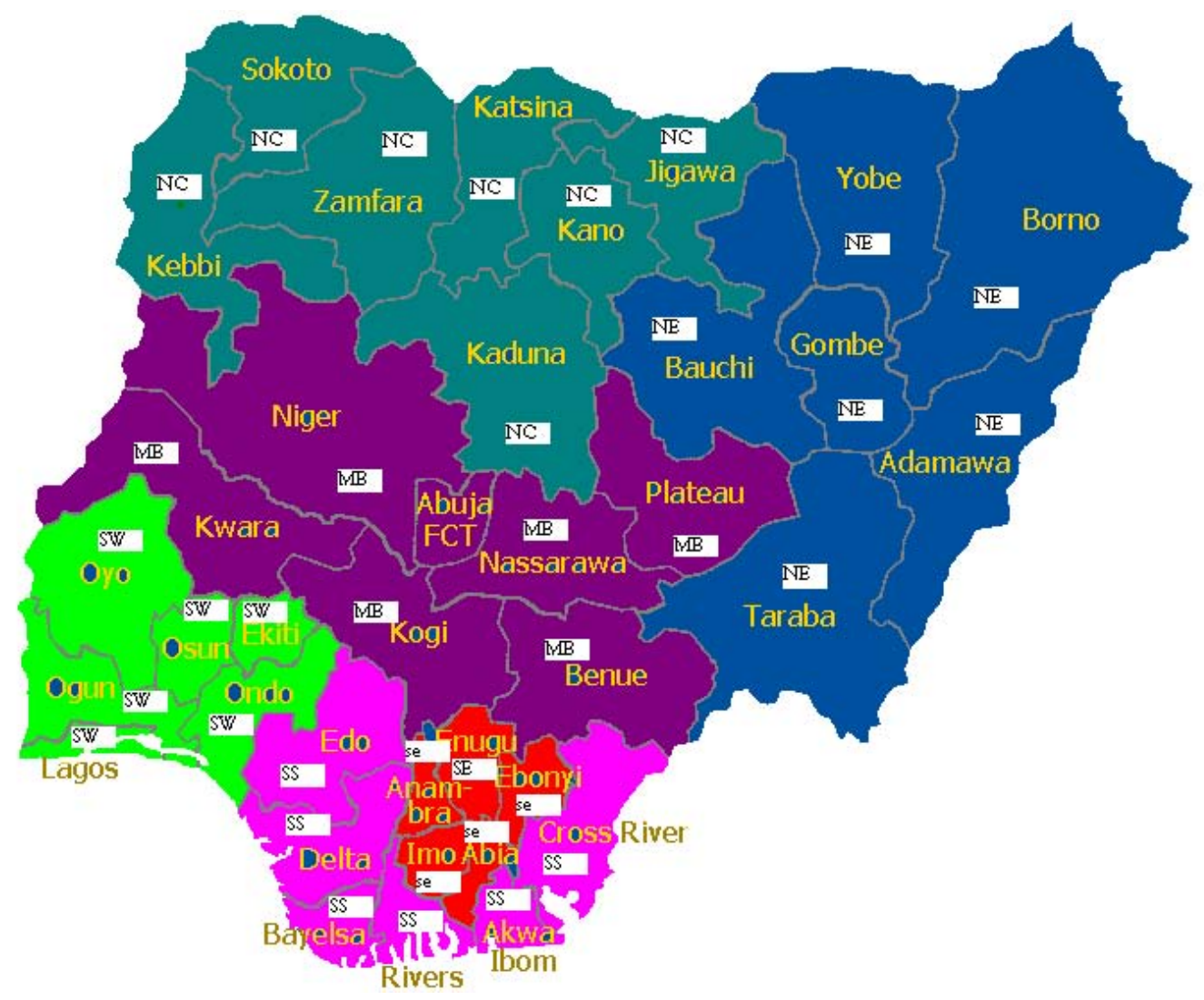

Figure 1: Geopolitical Regions in Nigeria

Color Code: Red-South East, Light Green-South West, Purple- Mid Belt, Pink-South South, Sea green-North Central and Dark blue-North East. 
Table 1: Regional Characteristic

\begin{tabular}{|c|c|c|c|c|c|c|}
\hline \multirow[t]{2}{*}{ Characteristics } & \multicolumn{2}{|c|}{ North } & \multirow{2}{*}{$\begin{array}{l}\text { South West } \\
\text { (South West) } \\
\end{array}$} & \multicolumn{2}{|c|}{ South East } & \multirow{2}{*}{$\begin{array}{l}\text { Middle } \\
\text { (Mid Belt) } \\
\end{array}$} \\
\hline & (North East) & (North Central) & & (South East) & (South South) & \\
\hline $\begin{array}{c}\text { Major } \\
\text { Languages }\end{array}$ & $\begin{array}{l}\text { Kanuri } \\
\text { Fulani }\end{array}$ & Hausa, Fulani & Yoruba & Ibo & $\begin{array}{c}(\text { over 10) } \\
\text { main languages }\end{array}$ & Nupe, Tiv \\
\hline $\begin{array}{l}\text { Major } \\
\text { Religions }\end{array}$ & Islam & Islam & $\begin{array}{l}\text { Christianity, } \\
\text { Islam \& TR }\end{array}$ & Christianity & Christianity & $\begin{array}{l}\text { Islam, } \\
\text { Christianity } \\
\text { TR }\end{array}$ \\
\hline \# of States & 6 & 7 & 6 & 5 & 6 & 7 \\
\hline $\begin{array}{l}\text { Major } \\
\text { Ethnicity }\end{array}$ & $\begin{array}{l}\text { Kanuri, Fulani } \\
\text { Jukuns } \\
\text { Hausa }\end{array}$ & Hausa-Fulani & Yoruba & Igbo & $\begin{array}{c}\text { Itsekiris, Isokos, } \\
\text { Edos, Urhobos } \\
\text { Efik, Ibibios } \\
\text { Kalabaris }\end{array}$ & $\begin{array}{l}\text { Igalas, Tivs } \\
\text { Nupe } \\
\text { Idoma }\end{array}$ \\
\hline $\begin{array}{c}\text { Major } \\
\text { Pre-colonial } \\
\text { Empires }\end{array}$ & $\begin{array}{l}\text { The Borno } \\
\text { Empire }\end{array}$ & $\begin{array}{l}\text { The Hausa } \\
\text { Empire }\end{array}$ & $\begin{array}{l}\text { The Oyo } \\
\text { Empire }\end{array}$ & $\begin{array}{l}\text { The Village } \\
\text { Councils }\end{array}$ & $\begin{array}{l}\text { The Benin } \\
\text { and Opobo } \\
\text { Kingdoms }\end{array}$ & $\begin{array}{l}\text { The Nupe and } \\
\text { Kwororofa } \\
\text { Kingdoms }\end{array}$ \\
\hline $\begin{array}{l}\text { Major Crops/ } \\
\text { natural } \\
\text { Resources }\end{array}$ & $\begin{array}{c}\text { Cotton, } \\
\text { groundnut, livestock, } \\
\text { Sugarcane }\end{array}$ & $\begin{array}{c}\text { Groundnut, Cattle, } \\
\text { Cotton, } \\
\text { Tobacco }\end{array}$ & $\begin{array}{c}\text { Cocoa, } \\
\text { Rubber, } \\
\text { Palm produce }\end{array}$ & $\begin{array}{c}\text { Coal, } \\
\text { Palm produce }\end{array}$ & $\begin{array}{l}\text { Oil and gas, } \\
\text { Palm, } \\
\text { Rubber }\end{array}$ & $\begin{array}{l}\text { Rice, } \\
\text { Soya beans }\end{array}$ \\
\hline $\begin{array}{c}\text { Main } \\
\text { Occupations }\end{array}$ & Farmers & Farmers, & $\begin{array}{l}\text { Farmers } \\
\text { Traders }\end{array}$ & $\begin{array}{l}\text { Traders, } \\
\text { Farmers }\end{array}$ & $\begin{array}{c}\text { Farmers, } \\
\text { Fishermen, Traders }\end{array}$ & $\begin{array}{l}\text { Farmers, } \\
\text { Fishermen }\end{array}$ \\
\hline Climate & Savanna & Savanna & Tropical & Tropical & $\begin{array}{l}\text { Rain forest } \\
\text { (equatorial) }\end{array}$ & Tropical \\
\hline
\end{tabular}

* TR means traditional religions *There are several other languages and ethnic groups in each region. I am only highlighting the dominant ones in terms of size in each region.

Table 2: Summary Statistics

\begin{tabular}{cccc}
\hline \hline Year & $\begin{array}{c}1996 / 97 \\
(\mathrm{~S} . \mathrm{D})\end{array}$ & $\begin{array}{c}1997 / 98 \\
(\mathrm{~S} . \mathrm{D})\end{array}$ & $\begin{array}{c}1998 / 99 \\
(\mathrm{~S} . \mathrm{D})\end{array}$ \\
\hline Observations & 94,691 & 131,477 & 106,325 \\
\hline Age & 23.12 & 23.486 & 23.32 \\
& $(17.93)$ & $(18.049)$ & $(18.21)$ \\
Sex (male=1) & 0.517 & 0.523 & 0.516 \\
& $(0.50)$ & $(0.499)$ & $(0.50)$ \\
Sector (urban=1) & 0.231 & 0.241 & 0.236 \\
& $(0.42)$ & $(0.427)$ & $(0.425)$ \\
Years sch & 4.08 & 4.17 & 4.14 \\
& $(5.09)$ & $(5.08)$ & $(5.136)$ \\
HH size & 6.08 & 6.12 & 6.337 \\
& $(3.32)$ & $(3.34)$ & $(3.5)$ \\
Income & 187.29 & 92.672 & 93.73 \\
& $(997.6)$ & $(298.298)$ & $(158.7)$ \\
\hline \hline
\end{tabular}

* Note monthly mean income here is for those working. Note the 1996 mean income is high because of a sizeable number of very high income earners in the dataset, this dispersion is reflected in the standard deviation. The mean incomes falls to 110.65 if these (about 265 observations) are eliminated with a s.d of 273.24 . 
Table 3: Real mean household income by region

\begin{tabular}{|c|c|c|c|c|c|c|c|}
\hline \multirow[t]{2}{*}{ Zones } & \multicolumn{2}{|c|}{ 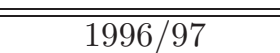 } & \multicolumn{2}{|c|}{ 1997/98 } & \multicolumn{2}{|c|}{ "1998/99 } & pooled \\
\hline & $\mathrm{N}$ & Mean(SE) & $\mathrm{N}$ & Mean(SE) & $\mathrm{N}$ & Mean(SE) & Mean(SE) \\
\hline N. East & 5011 & $\begin{array}{l}244.6 \\
(20.7)\end{array}$ & 5639 & $\begin{array}{l}92.95 \\
(7.00)\end{array}$ & 4379 & $\begin{array}{l}72.65 \\
(1.78)\end{array}$ & $\begin{array}{c}139.63 \\
(7.74)\end{array}$ \\
\hline N. Central & 6003 & $\begin{array}{c}139.07 \\
(8.3)\end{array}$ & 6705 & $\begin{array}{l}79.03 \\
(2.21)\end{array}$ & 5220 & $\begin{array}{l}83.04 \\
(3.13)\end{array}$ & $\begin{array}{l}99.82 \\
(3.22)\end{array}$ \\
\hline M. Belt & 6974 & $\begin{array}{c}384.15 \\
(19.4)\end{array}$ & 7291 & $\begin{array}{l}92.23 \\
(2.2)\end{array}$ & 5624 & $\begin{array}{c}102.38 \\
(2.49)\end{array}$ & $\begin{array}{c}209.28 \\
(7.72)\end{array}$ \\
\hline S. East & 4886 & $\begin{array}{l}97.75 \\
(2.14)\end{array}$ & 5514 & $\begin{array}{l}94.86 \\
(1.76)\end{array}$ & 4030 & $\begin{array}{l}101.44 \\
(2.11)\end{array}$ & $\begin{array}{c}96.94 \\
(1.11)\end{array}$ \\
\hline S. West & 6018 & $\begin{array}{c}117.06 \\
(8.36)\end{array}$ & 7123 & $\begin{array}{l}94.20 \\
(1.14)\end{array}$ & 5712 & $\begin{array}{l}99.26 \\
(1.28)\end{array}$ & $\begin{array}{c}100.43 \\
(2.36)\end{array}$ \\
\hline S. South & 5881 & $\begin{array}{l}100.97 \\
(1.65)\end{array}$ & 6300 & $\begin{array}{l}102.37 \\
(5.49)\end{array}$ & 5277 & $\begin{array}{l}100.11 \\
(1.98)\end{array}$ & $\begin{array}{l}101.49 \\
(2.37)\end{array}$ \\
\hline
\end{tabular}

* Note Income is in real terms and currency is Naira

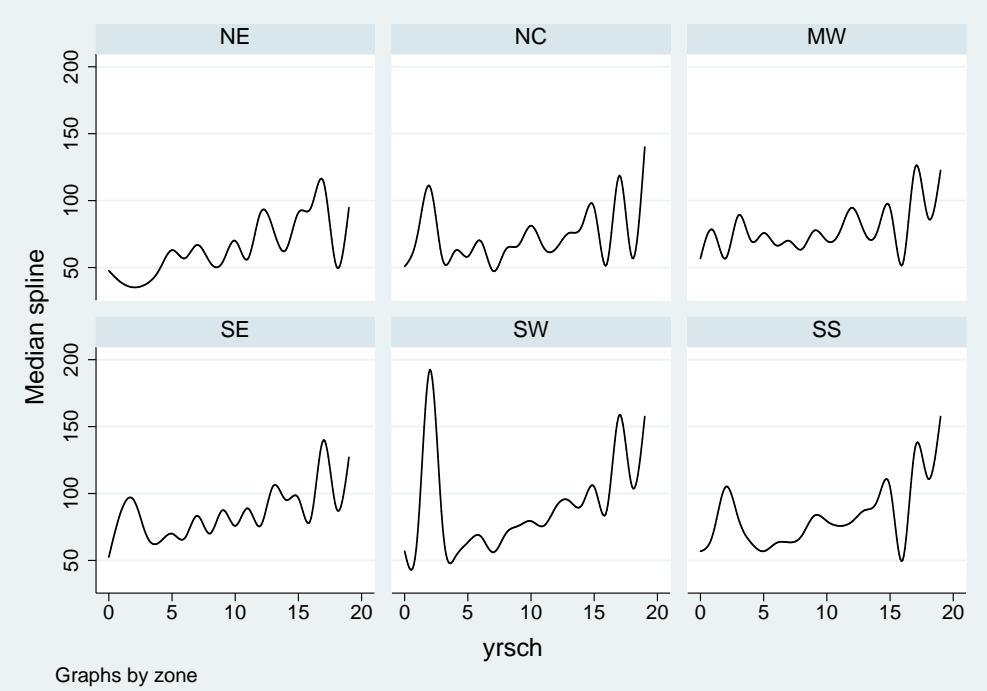

Figure 2: Median spline of Income by school attainment across regions in Nigeria 
Table 4: Real mean income by region \& education level 1996/97

\begin{tabular}{ccccccccccc}
\hline \hline \multirow{2}{*}{ Region } & \multicolumn{2}{c}{ No education } & \multicolumn{2}{c}{ Some Primary } & \multicolumn{2}{c}{ Full Primary } & \multicolumn{2}{c}{ Full Secondary } & \multicolumn{2}{c}{ Tertiary } \\
\cline { 2 - 10 } & $\mathrm{N}$ & Mean(SE) & $\mathrm{N}$ & Mean(SE) & $\mathrm{N}$ & Mean(SE) & $\mathrm{N}$ & Mean(SE) & $\mathrm{N}$ & Mean(SE) \\
\hline N. East & \multirow{2}{*}{3850} & 252.02 & 155 & 213.94 & 557 & 185.1 & 327 & 268.35 & 128 & 250.77 \\
& & $(24.64)$ & & $(121.9)$ & & $(57.4)$ & & $(50.75)$ & $(63.9)$ \\
N. Central & \multirow{2}{*}{4994} & 130.46 & \multirow{2}{*}{179} & 388.9 & 476 & 143.59 & 242 & 113.29 & 112 & 159.93 \\
& & $(8.73)$ & & $(118.4)$ & & $(22.58)$ & & $(8.09)$ & & $(16.0)$ \\
Mid Belt & \multirow{2}{*}{4001} & 514.82 & \multirow{2}{*}{199} & 150.65 & \multirow{2}{*}{1460} & 258.66 & 880 & 163.5 & 435 & 155.88 \\
& & $(31.42)$ & & $(45.61)$ & & $(28.3)$ & & $(25.17)$ & $(19.5)$ \\
S.East & \multirow{2}{*}{1442} & 74.16 & \multirow{2}{*}{472} & 93.65 & \multirow{2}{*}{1989} & 101.52 & 754 & 122.19 & 229 & 141.47 \\
& & $(3.05)$ & & $(3.7)$ & & $(4.37)$ & & $(3.83)$ & $(6.02)$ \\
S. West & \multirow{2}{*}{2276} & 72.65 & \multirow{2}{*}{205} & 144.25 & \multirow{2}{*}{1840} & 119.74 & 1250 & 169.23 & 447 & 173.82 \\
& & $(1.25)$ & & $(43.9)$ & & $(17.29)$ & & $(30.0)$ & & $(8.44)$ \\
S. South & \multirow{2}{*}{1494} & 86.53 & \multirow{2}{*}{491} & 84.67 & 2335 & 94.46 & 1237 & 122.59 & 382 & 154.96 \\
& & $(3.82)$ & & $(5.21)$ & & $(2.26)$ & & $(3.93)$ & & $(5.65)$ \\
\hline \hline
\end{tabular}

Table 5: Real mean income by region \& education level 1997/98

\begin{tabular}{|c|c|c|c|c|c|c|c|c|c|c|}
\hline \multirow{2}{*}{ Region } & \multicolumn{2}{|c|}{ No education } & \multicolumn{2}{|c|}{ Some Primary } & \multicolumn{2}{|c|}{ Full Primary } & \multicolumn{2}{|c|}{ Full Secondary } & \multicolumn{2}{|c|}{ Tertiary } \\
\hline & $\mathrm{N}$ & Mean(SE) & $\mathrm{N}$ & Mean(SE) & $\mathrm{N}$ & Mean(SE) & $\mathrm{N}$ & Mean(SE) & $\mathrm{N}$ & Mean(SE) \\
\hline $\mathrm{NE}$ & 4374 & $\begin{array}{l}87.68 \\
(8.74)\end{array}$ & 144 & $\begin{array}{l}86.95 \\
(7.68)\end{array}$ & 667 & $\begin{array}{c}104.19 \\
(8.27)\end{array}$ & 374 & $\begin{array}{c}116.5 \\
(19.46)\end{array}$ & 80 & $\begin{array}{l}188.17 \\
(48.5)\end{array}$ \\
\hline $\mathrm{NC}$ & 5533 & $\begin{array}{l}74.06 \\
(2.58)\end{array}$ & 143 & $\begin{array}{l}87.39 \\
(8.87)\end{array}$ & 559 & $\begin{array}{l}97.12 \\
(4.52)\end{array}$ & 334 & $\begin{array}{l}100.68 \\
(5.56)\end{array}$ & 136 & $\begin{array}{l}144.89 \\
(12.84)\end{array}$ \\
\hline MB & 4016 & $\begin{array}{l}83.73 \\
(3.14)\end{array}$ & 301 & $\begin{array}{l}124.59 \\
(19.37)\end{array}$ & 1578 & $\begin{array}{l}95.67 \\
(4.38)\end{array}$ & 944 & $\begin{array}{l}93.84 \\
(2.83)\end{array}$ & 452 & $\begin{array}{l}130.84 \\
(6.15)\end{array}$ \\
\hline $\mathrm{SE}$ & 1629 & $\begin{array}{l}67.09 \\
(1.74)\end{array}$ & 498 & $\begin{array}{l}94.79 \\
(3.41)\end{array}$ & 2227 & $\begin{array}{l}95.19 \\
(3.56)\end{array}$ & 935 & $\begin{array}{l}128.5 \\
(4.33)\end{array}$ & 225 & $\begin{array}{c}152.98 \\
(7.2)\end{array}$ \\
\hline SW & 2685 & $\begin{array}{l}72.56 \\
(1.27)\end{array}$ & 221 & $\begin{array}{l}78.94 \\
(5.8)\end{array}$ & 2196 & $\begin{array}{l}92.24 \\
(2.02)\end{array}$ & 1518 & $\begin{array}{l}110.8 \\
(2.46)\end{array}$ & 503 & $\begin{array}{c}174.92 \\
(7.38)\end{array}$ \\
\hline SS & 1653 & $\begin{array}{l}85.28 \\
(3.65)\end{array}$ & 536 & $\begin{array}{l}149.84 \\
(62.23)\end{array}$ & 2560 & $\begin{array}{l}90.62 \\
(1.88)\end{array}$ & 1241 & $\begin{array}{c}114.26 \\
(3.03)\end{array}$ & 310 & $\begin{array}{l}160.94 \\
(10.89)\end{array}$ \\
\hline
\end{tabular}

Table 6: Real mean income by region \& education level 1998/99

\begin{tabular}{|c|c|c|c|c|c|c|c|c|c|c|}
\hline \multirow{2}{*}{ Region } & \multicolumn{2}{|c|}{ No education } & \multicolumn{2}{|c|}{ Some Primary } & \multicolumn{2}{|c|}{ Full Primary } & \multicolumn{2}{|c|}{ Full Secondary } & \multicolumn{2}{|c|}{ Tertiary } \\
\hline & $\mathrm{N}$ & Mean(SE) & $\mathrm{N}$ & Mean(SE) & $\mathrm{N}$ & Mean(SE) & $\mathrm{N}$ & Mean(SE) & $\mathrm{N}$ & Mean(SE) \\
\hline $\mathrm{NE}$ & 3419 & $\begin{array}{l}67.52 \\
(2.03)\end{array}$ & 124 & $\begin{array}{l}82.33 \\
(7.78)\end{array}$ & 427 & $\begin{array}{l}80.88 \\
(3.94)\end{array}$ & 319 & $\begin{array}{l}89.74 \\
(4.68)\end{array}$ & 90 & $\begin{array}{l}154.49 \\
(24.97)\end{array}$ \\
\hline $\mathrm{NC}$ & 4325 & $\begin{array}{l}79.03 \\
(3.70)\end{array}$ & 85 & $\begin{array}{l}72.29 \\
(4.55)\end{array}$ & 386 & $\begin{array}{l}93.81 \\
(6.36)\end{array}$ & 280 & $\begin{array}{l}104.01 \\
(4.65)\end{array}$ & 144 & $\begin{array}{l}140.17 \\
(11.67)\end{array}$ \\
\hline MB & 3026 & $\begin{array}{l}85.91 \\
(1.88)\end{array}$ & 244 & $\begin{array}{l}116.49 \\
(13.77)\end{array}$ & 1232 & $\begin{array}{c}109.39 \\
(7.76)\end{array}$ & 740 & $\begin{array}{c}114.69 \\
(6.03)\end{array}$ & 382 & $\begin{array}{c}177.3 \\
(16.48)\end{array}$ \\
\hline $\mathrm{SE}$ & 1259 & $\begin{array}{l}76.70 \\
(3.43)\end{array}$ & 419 & $\begin{array}{l}98.13 \\
(6.7)\end{array}$ & 1581 & $\begin{array}{c}103.66 \\
(3.19)\end{array}$ & 600 & $\begin{array}{c}136.42 \\
(6.72)\end{array}$ & 171 & $\begin{array}{l}148.47 \\
(8.94)\end{array}$ \\
\hline SW & 2099 & $\begin{array}{l}70.32 \\
(1.23)\end{array}$ & 228 & $\begin{array}{l}76.06 \\
(4.06)\end{array}$ & 1710 & $\begin{array}{l}93.76 \\
(2.06)\end{array}$ & 1215 & $\begin{array}{c}127.16 \\
(3.13)\end{array}$ & 460 & $\begin{array}{c}189.58 \\
(7.71)\end{array}$ \\
\hline SS & 1398 & $\begin{array}{l}82.77 \\
(4.83)\end{array}$ & 490 & $\begin{array}{l}85.04 \\
(3.99)\end{array}$ & 2055 & $\begin{array}{l}93.50 \\
(2.34)\end{array}$ & 1054 & $\begin{array}{c}120.13 \\
(3.62)\end{array}$ & 280 & $\begin{array}{l}186.22 \\
(15.42)\end{array}$ \\
\hline
\end{tabular}


Table 7: Estimates of returns to education by region (OLS)

\begin{tabular}{ccccccc}
\hline \hline & \multicolumn{6}{c}{ Regions } \\
\cline { 2 - 7 } & North East & North Central & Mid Belt & South East & South West & South South \\
\hline OLS & $0.029^{*}$ & $0.035^{*}$ & $0.023^{*}$ & $0.051^{*}$ & $0.049^{*}$ & $0.041^{*}$ \\
SE & $(0.002)$ & $(0.001)$ & $(0.001)$ & $(0.002)$ & $(0.001)$ & $(0.002)$ \\
Controls & Yes & Yes & Yes & Yes & Yes & Yes \\
\hline *1\% significance level,
\end{tabular}

Table 8: IV Estimates of Returns to Schooling (1st Stage)

\begin{tabular}{|c|cc|}
\hline \hline Region & & \\
\cline { 2 - 3 } & OLS & IV \\
\hline North & NA & $0.366^{*}$ \\
& & $(0.036)$ \\
South & NA & $0.124^{*}$ \\
& & $(0.017)$ \\
Controls & Yes & Yes \\
\hline \hline
\end{tabular}

Note: Estimates presented are estimates of the impact of the instrument on schooling.

Table 9: Estimates of Returns to Education (2nd Stage)

\begin{tabular}{|c|cc|}
\hline \hline Region & & \\
\cline { 2 - 3 } & OLS & IV \\
\hline North & $0.017^{*}$ & $0.043^{*}$ \\
& $(0.001)$ & $(0.01)$ \\
South & $0.031^{*}$ & $0.054^{*}$ \\
& $(0.001)$ & $(0.017)$ \\
Controls & Yes & Yes \\
\hline \hline
\end{tabular}

Note: $* 5 \%$ significance level 